\title{
MEMBANGUN BUDAYA HUKUM INDONESIA DI ERA GLOBALISASI
}

\author{
Riski Febria Nurita ${ }^{1}$, Laga Sugiarto ${ }^{2}$
}

\begin{abstract}
ABSTRAK
Jika hari ini kita berbicara tentang sebuah negara yang disebut Republik Indonesia maka kita akan banyak bicara tentang korupsi, penyuapan, konflik baik konflik internal dalam tiga lembaga tertinggi di Indonesia maupun konflik eksternal di luar lembaga-lembaga negara, pertempuran antara siswa serta perkelahian antar warga di Indonesia sendiri, penganiayaan, pembunuhan, pemerkosaan dan banyak lainnya yang kita miliki sendiri telah merasa malu untuk membicarakannya karena hal-hal ini tidak akan ada akhirnya. Apalagi jika kita berbicara tentang hukum di era globalisasi ,kita akan berbicara tentang hukum di Indonesia dengan nama ketidakadilan, keberpihakan, keberpihakan, bukan otonomi dan lain-lain. Hal-hal ini ketika kita melihat kembali dengan hati-hati, kita akan menemukan sesuatu yang disebut "budaya hukum", karena budaya hukum adalah penentu di mana sistem hukum ditempatkan di tempat yang sah dengan nilai-nilai di dalamnya yang nilai sosial sebagai hukum yang dibuat ditujukan untuk orang-orang di suatu negara sendiri untuk mengatur semua perilaku orangorang di negara yang mengeluarkan hukum. Budaya hukum di Indonesia sendiri telah tergusur oleh budaya hukum baru yang disebabkan oleh banyak hal misalnya pesatnya kemajuan teknologi seolaholah kita dapat melintasi batas antar negara, perkembangan perdagangan bebas di Indonesia, informasi yang semakin banyak dan masih banyak penyebab lainnya. Penyebabnya adalah meninggalkan dampak yang baik pada negara kita misalnya, hanya di bidang hukum, dengan kemajuan teknologi informasi kita dapat menentukan bagaimana penerapan hukum di negara-negara yang lain sehingga kita dapat meningkatkan sistem hukum di negara kita sendiri jika dinilai kurang baik maka kita dapat mengambil contoh penerapan hukum di negara lain. Selain dampak positif yang dibuat oleh banyak kemajuan di era globalisasi, dampak negatif juga turut serta mewarnai segala sesuatunya di negara kita. Misalnya, hanya dengan munculnya budaya pemikiran barat kita menjadi barat. Demikian pula kita dapat melihat awal negara kita adalah negara demokratis dari rakyat dan untuk orang-orang serba sosial dan kepentingan sosial tetap jadi kali ini secara tidak langsung kami negara bergeser ke negara liberal yaitu masyarakat yang paling memiliki semangat individualisme, ekonomi bergeser yang semula menyombongkan diri tentang ekonomi yang demokratis di negara ini menjadi ekonomi kapitalisme telah terbukti di negara kita yang berkuasa pada titik mana pun pulsa ekonomi adalah modal tinggi dan bahwa tidak ada modal masih marginal klan di negara mereka sendiri tanpa ada perubahan dari tahun ke tahun. Pergeseran yang merupakan subyek penulis penelitian yang akan dijelaskan satu per satu dimulai dari keadaan awal budaya hukum di Indonesia, penetrasi barat masuk di Indonesia, budaya hukum negara di Indonesia setelah penetrasi barat masuk, hingga Bagaimana mengembalikan budaya hukum Indonesia yang telah mengungsi dalam arti pergeseran arah negatif.
\end{abstract}

Kata Kunci: Budaya Hukum, Hukum Indonesia, Era Globalisasi

\section{ABSTRACT}

If today we are talking about a country called the Republic of Indonesia then we will not be much to talk about corruption, bribery, conflicts both internal conflict within the three highest institution in Indonesia as well as external conflict outside the institutions of the country, fighting between students as well as fighting between citizens in Indonesia itself, persecution, murder, rape and many others

$1 \quad$ Fakultas Hukum Universitas Merdeka Malang,Universitas Negeri Semarang, email: riski.febria@unmer.ac.id

2 Fakultas Hukum Universitas Merdeka Malang,Universitas Negeri Semarang, email: laga.sugiarto@gmail.com 
that we actually own has been embarrassed to talk about it because these things will not be there eventually. Especially if we are talking about the law in the era of globalization we are not going away talking about the law in Indonesia with the name of injustice,alignments, partiality, not autonomy and others. These things when we look back carefully, we will find something called "legal culture", because the legal culture is the determinant of where the legal system is placed in its rightful place with the values in it that is of social value as a law made is intended for people in a country itself to regulate all behavior of the people in the country that issued the law. Legal culture in Indonesia itself has been displaced by a culture new law caused by many things for example the rapid advancement of technology as if we can cross the boundary between countries, the development of free trade in Indonesia, information increasingly and still many other causes. The causes are the leave a good impact on our country for example, just in the field of law, with the advancement of information technology we can determine how the application of the law in the countries of the other so that we can improve a system of law in our own country if rated less well then we can take the example of the application of the law in other countries. In addition to the positive impact made by many advances in the era of globalization, the negative impact also participated and coloring everything in our country. For example, just by the appearance of a culture of western thought we became western Similarly we can see the beginning of our country is a democratic state of the people and for the people all-round social and the social interest anyway so this time indirectly our country shifted to a liberal state that is society most have a spirit of individualism, the economy shifted that originally brag about a democratic economy in this country to be an economy of capitalism has been proven in our country in power at any point economic pulse is the capital high and that no capital is still the clans marginal in their own country without any change from year to year. Shifts which is the subject of study authors that will be described one by one starting from the initial state of the legal culture in Indonesia, penetration western entering in Indonesia, state legal culture in Indonesia after the penetration of western is entered, up to How to restore the legal culture of Indonesia that has been displaced in the sense of a shift in the negative direction.

Keywords: $\quad$ Legal Culture, Indonesia Law, Globalization Era

\section{PENDAHULUAN}

Apabila saat ini kita membicarakan suatu negara yang disebut Republik Indonesia maka kita tidak akan jauh dengan pembicaraan mengenai korupsi, suap-menyuap, konflik baik konflik internal di dalam tiga lembaga tertinggi di Indonesia maupun konflik eksternal di luar lembaga-lembaga negara tersebut, tawuran antar pelajar maupun tawuran antar warga negara di Indonesia itu sendiri, penganiayaan, pembunuhan, perkosaan dan masih banyak lagi yang lainnya yang sebenarnya kita sendiri telah jengah untuk membicarakannya karena hal-hal tersebut tidak akan ada akhirnya. Apalagi apabila kita membicarakan mengenai hukumnya di era globalisasi seperti saat ini kita tidak akan jauh-jauh membicarakan hukum di Indonesia dengan yang namanya ketidakadilan, kepemihakan, ketidaknetralan , ketidakotonoman dan lain sebagainya. Hal-hal tersebut apabila kita lihat kembali secara seksama maka kita akan menemukan sesuatu yang dinamakan "budaya hukum", karena budaya hukum merupakan penentu dimana sistem hukum ditempatkan di tempat yang selayaknya dengan nilai-nilai yang ada di dalamnya yaitu nilai sosial karena suatu hukum dibuat memang diperuntukkan 
bagi masyarakat dalam suatu negara itu sendiri guna mengatur segala tingkah laku masyarakat di dalam negara yang mengeluarkan hukum tersebut.

Budaya hukum di Indonesia sendiri telah tergeser dengan suatu budaya hukum yang baru yang disebabkan oleh berbagai hal misalnya saja semakin majunya teknologi seolah-olah kita dapat melintasi tapal batas antar negara, semakin berkembangnya perdagangan bebas di Indonesia, informasi-informasi yang semakin ter update dan masih banyak penyebab yang lainnya. Penyebab-penyebab tersebut pada dasarnya memberikan dampak yang baik bagi negara kita contohnya saja dalam bidang hukum maka dengan adanya kemajuan teknologi informasi kita dapat mengetahui bagaimana penerapan-penerapan hukum di negara-negara yang lainnya sehingga kita dapat memperbaiki suatu sistem hukum di negara kita sendiri apabila dinilai kurang baik maka kita dapat mengambil contoh penerapan-penerapan hukum di negara-negara yang lainnya. Selain dampak positif yang telah diberikan oleh berbagai kemajuan di era globalisasi ini dampak negatif pun turut serta mewarnai segala sesuatunya di negara kita. Contohnya saja dengan masuknya budaya western pemikiran kita pun menjadi western pula dapat kita lihat yang awalnya negara kita merupakan negara demokratis dari rakyat dan untuk rakyat semua serba sosial dan bagi kepentingan sosial pula maka saat ini secara tidak langsung negara kita bergeser menjadi negara liberal yaitu masyarakat yang kebanyakan memiliki jiwa individualisme, perekonomiannya pun bergeser yang awalnya di gembar-gemborkan suatu ekonomi kerakyatan di negara ini menjadi ekonomi kapitalisme sudah dibuktikan di negara kita yang berkuasa di setiap titik nadi perekonomian adalah yang bermodal tinggi dan yang tidak memiliki modal tetaplah menjadi kaum-kaum marginal di negeri sendiri tanpa adanya perubahan dari tahun ke tahun.

Pergeseran-pergeseran inilah yang menjadi bahan kajian penulis yang akan diuraikan satu persatu mulai dari keadaan awal budaya hukum di Indonesia, penetrasi western yang masuk di Indonesia , Keadaan budaya hukum di Indonesia setelah penetrasi western tersebut masuk, hingga Bagaimana cara mengembalikan budaya hukum Indonesia yang telah tergeser dalam arti pergeseran ke arah negatif.

Adapun rumusan masalah terhadap isu yan diuraikan di atas adalah sebagai berikut: Bagaimana mengembalikan budaya hukum Indonesia di era globalisasi dan westernisasi? 


\section{METODE PENELITIAN}

Penelitian ini menggunakan pendekatan penelitian Normatif dengan pendekatan melalui analisa terhadap peraturan-peraturan dalam hukum Nasional dan Internasional (statue approach) dan juga menggunakan studi kasus (case study) mengenai representasi kepemimpinan wanita dalam birokrasi di Indonesia yang sudah ada. Secara normatif berarti penelitian hukum meletakkan hukum sebagai sebuah bangunan sistem norma. Sistem norma yang dimaksud adalah mengenai asas-asas, norma, kaidah, dan peraturan perundangundangan, putusan pengadilan, perjanjian serta doktrin (ajaran) ${ }^{3}$. Peter Mahmud Marzuki menjelaskan penelitian hukum normatif adalah suatu proses untuk menemukan suatu aturan hukum, prinsip-prinsip hukum, maupun doktrin-doktrin hukum untuk menjawab permasalahan hukum yang dihadapi ${ }^{4}$.

\section{HASIL PENELITIAN DAN PEMBAHASAN}

\section{Hukum Dan Nilai Sosial Budaya}

Antara hukum di satu pihak dengan nilai-nilai sosial-budaya di lain pihak terdapat kaitan yang erat Hal ini telah dibuktikan berkat penyelidikan beberapa ahli antropologi hukum. Kaitan yang erat antara hukum dan nilai-nilai sosial budaya masyarakat itu ternyata bahwa hukum yang baik tidak lain adalah hukum yang mencerminkan nilai-nilai yang hidup dalam masyarakat. ${ }^{5}$ Indonesia masa kini berada dalam masa transisi, yaitu sedang terjadi perubahan nilai-nilai yang bersifat tradisional ke nilai-nilai yang modern.Namun, masihmenjadi persoalan nilai-nilai manakah yang hendak ditinggalkan dan nilai-nilai baru mana yang akan menggantikannya. Sudah barang tentu dalam proses perubahan ini akan banyak dihadapi hambatan- hambatan yang kadang-kadang akan menimbulkan keresahan-keresahan maupun kegoncangan di dalam masyarakat. Mochtar Kusumaatmadja misalnya ,mengemukakan beberapa hambatan utama seperti jika yang akan diubah itu identik dengan kepribadian nasional, sikap golongan intelektual dan pimpinan masyarakat yang tidak mempraktekkan nilai-nilai yang dianjurkan di samping sifat heterogenitas bangsa Indonesia, yang baik tingkat kemajuannya, agama serta bahasanya berbeda satu dengan lainnya. ${ }^{6}$

\footnotetext{
Dr. Mukti Fajar ND dan Yulianto Ahmad, 2010,Dualisme Penelitian Hukum Normatif dan Empiris, Yogyakarta: Pustaka Pelajar, hlm.

Peter Mahmud Marzuki, 2005,Penelitian Hukum, Jakarta: Kencana, hlm. 35.

Lili Rasjidi , Dasar-dasar Filsafat dan Teori Hukum, Bandung: Alumni,2007, hlm. 80-81

Lili Rasjidi. Ibid, hlm 81
} 


\section{Sebab-Sebab Masyarakat Mentaati Hukum}

Filsafat hukum mencoba mencari dasar kekuatan mengikat daripada hukum, yaitu apakah ditaatinya hukum itu disebabkan oleh hukum itu dibentuk oleh pejabat yang berwenang atau memang masyarakat mengakuinya karena hukum tersebut dinilai sebagai suatu hukum yang hidup di dalam masyarakat itu.

\section{Sebab Negara Berhak Menghukum Seseorang}

Pada waktu mengulas tentang dasar kekuatan mengikat dari hukum sebagai jawaban atas pertanyaan apakah sebabnya orang menaati hukum, kita mengenal beberapa teori seperti teori kedaulatan tuhan, perjanjian masyarakat dan kedaulatan negara. Jika ditelaah bunyi teori-teori termaksud, maka tampaknya bahwa dalam usaha menjawab dasar mengikat sesuatu hukum tersirat juga ulasan wewenang negara untuk menghukum warganya terutama atas segala perbuatannya yang dapat menggoncangkan, membahayakan dan meruntuhkan sendi-sendi kehidupan masyarakat.

Kedaulatan tuhan misalnya deengan penganutnya yang sangat terkenal di abad ke -19 , Friedrich Julius Stahl berpendapat bahwa :

“Negara adalah badan yang mewakili Tuhan di dunia yang memiliki kekuasaan penuh untuk menyelenggarakan ketertiban hukum di dunia . Para pelanggar ketertiban itu perlu memperoleh hukuman agar ketertiban hukum tetap terjamin “

Teori perjanjian masyarakat mencoba menjawab pertanyaan tersebut di atas dengan mengemukakan otoritas negara yang bersifat monopoli itu pada kehendak manusia itu sendiri yang menghendaki adanya kedamaian dan ketentraman di masyarakat. Mereka berjanji akan menaati segala ketentuan yang dibuat negara di lain pihak bersedia pula untuk memperoleh hukuman jika dipandang tingkah lakunya akan berakibat terganggunya ketertiban dalam masyarakat. Mereka telah memberikan kuasa kepada negara untu menghukum seseorang yang melanggar ketertiban.

Penganut-penganut teori kedaulatan negara mengemukakan pendirian yang lebih tegas.Karena negaralah yang berdaulat, maka hanya negara itu sendiri yang berhak menghukum seseorang yang mencoba mengganggu ketertiban dalam masyarakat. Negaralah yang menciptakan hukum, Jadi, adanya hukum itu karena adanya negara , dan tidak ada satu hukum pun yang berlaku jika tidak dikehendaki oleh negara. 
Dalam kaitan dengan hukuman, hukum ciptaan negara itu adalah hukum pidana.Walaupun terdapat berbagai teori seperti tersebut di atas, sesungguhnya hak negara untuk menghukum seseorang didasari pemikiran bahwa negara memiliki tugas berat, yaitu berusaha mewujudkan segala tujuanyang menjadi cita-cita dan keinginan seluruh warganya.

Usaha-usaha yang berupa hambatan-hambatan, penyimpangan-penyimpangan terhadap perwujudan tujuan tadi patut dicegah dengan memberikan hukuman kepada pelakunya . Hanya dengan cara demikian, negara dapat melaksanakan tugasnya sebagaimana mestinya.

\section{Keadaan Awal Budaya Hukum Di Indonesia}

Uraian ini dimulai dengan apa yang bisa kita sebut dengan hukum adat, uraian ini mencoba untuk menarik kelanjutan tingkat teknologi serta budi daya masyarakat Indonesia pada waktu itu pada waktu itu ke arah manifestasi kebudayaannya , termasuk di dalamnya adalah hukum. Adapun kelanjutan-kelanjutan itu ditarik dari kenyataan-kenyataan yang berikut: ${ }^{7}$

1. Adaptasi yang agraris

2. Ketergantungan pada alam yang besar, terutama disebabkan oleh teknologi mesin yang belum berkembang

3. Pertanian yang subsisten

Kelanjutan-kelanjutan dari kenyataan-kenyataan yang demikian itu menyebabkan dipegangnya nilai-nilai berikut :

1. Keterikatan kepada sesama anggota masyarakat yang besar

2. Penghormatan terhadap alam dan kepercayaan akan adanya kekuatan-kekuatan yang tidak tampak

3. Kepatuhan kepada pemimpin sebagai syarat bagi kelangsungan kehidupan masyarakat

Pada masyarakat adat pada saat itu keterikatan yang terlihat jelas adalah keterikatan terhadap tanah yaitu tanah dianggap sebagai sumber utama dalam pereekonomian masyarakat adat, hingga terdapat pula penggolongan penduduk desa seperti terdapat di Jawa. Penggolongan tersebut adalah pengaitan status seseorang di desa kepada hubungannya dengan tanah.Warga desa ini digolongkan ke dalam: ${ }^{8}$

Satjipto Rahardjo , Hukum dan Perubahan sosial, Bandung : Alumni, 1983, hlm. 92. 
1. Warga inti ( pribumi, sikep, kuli, baku, gogol ), yaitu mereka yang memiliki tanah garapan dan tanah pekarangan dan yang memikul tanggung jawab sepenuhnya

2. Warga atau lapisan pemilik yang hanya mempunyai tanah pekarangan atau pemilik ladang ( lindung, indung ) yang memikul beberapa kewajiban

3. Lapisan yang memiliki rumah diatas tanah milik orang lain ( numpang)

4. Lapisan yang bekerja untuk orang tempat mereka tinggal (nusup, tlosor)

Unsur pembentuk persekutuan dari berbagai kategori keterikatan anggota-anggota masyarakat :

1. Berdirinya persekutuan diterima sebagai suatu keharusan alamiah dan dengan demikian suatu kenyataan yang bersifat metayuridis

2. Terdapat suatu susunan yang timbul dari dalam persekutuan dan yang menempatkan seseorang atau suatu kelompok pada kedudukan diatas yang lain. Dengan susunan dari dalam ini tentunya yang dimaksud adalah yang timbul dari adaptasi persekutuan itu terhadap lingkungannya

3. Terdapat benda-benda, tanah, air , tumbuh-tumbuhan, candi-candi , bangunanbangunan yang harus dipertahankan, pelihara dan sucikan

4. Tidak ada pikiran pada setiap orang tentang kemungkinan untuk membubarkan persekutuan mereka tersebut.

Untuk pemimpin pada masyarakat Indonesia asli sebetulnya adalah penjelmaan adat setempat. Pemimpin pada saat itu tugasnya lebih bersifat menyalurkan anggota-anggota masyarakat agar mereka ini berbuat sesuai dengan adat. Sama sekali tidak ada penggunaan paksaan, tidak ada sesuatu yang dibebankan dari atas.

\section{Masuknya Budaya Western Dalam Hukum Indonesia}

Masuknya budaya western atau barat dalam hukum Indonesia dimulai melalui suatu kontak, yang terlihat adalah pertemuan antara dua macam kebudayaan dan dalam perkembangannya menghasilkan suatu dominasi dari suatu kebudayaan atas kebudayaan lainnya yaitu dominasi budaya barat atas Indonesia. Kontak pertama dilakukan oleh para pedagang Belanda dalam rangka operasi perdagangan mereka. Pada akhirnya dalam perdagangan di Indonesia yang mereka jalankan mereka memiliki maksud untuk mendapatkan keuntungan sebesar-besarnya dari negara ini. Perubahan-perubahan yang ditimbulkan oleh pemerintah penjajah Belanda terhadap masyarakat Indonesia terjadi secara 
bertingkat-tingkat sesuai dengan tahap penetrasi yang berjalan. Berikut ini adalah penggambaran tingkat-tingkat tersebut. ${ }^{9}$

1. Tahap pertama dilalui dalam bentuk kontak antara para pedagang dengan raja-raja , sehingga perjanjian-perjanjian di situ juga berupa perjanjian-perjanjian dengan rajaraja. Keadaan ini berlangsung pada awal abad ke-17 dan tingkat penetrasi baru sampai pada lapisan atas masyarakat Indonesia.

2. Manakala kemudian politik pemerintah penjajah sekitar tahun 1800 bergeser ke arah pemanfaatan struktur feodal bagi tujuan-tujuan ekonomi , maka tahap penetrasi mulai masuk ke tingkat yang lebih rendah lagi, yaitu tingkat propinsi. Perjanjian-perjanjian dilakukan dalam bentuk kontrak dengan poara bupati yang disebut Acten Van Berband.

3. Pada pertengahan abad yang lampau tingkat penetrasi mulai masuk lebih dalam lagi sampai ke tingkat desa dengan bentuk-bentuk perjanjian yang diadakan antara residen dengan kepala desa.

4. Perubahan dalam eksploitasi ekonomi di Indonesia terjadi manakala pandangan liberalisme mulai menguasai pemikiran dunia. Pandangan tersebut pada pokoknya menghendaki campur tangan pemerintah di bidang ekonomi dibatasi sampai sekecilkecilnya dan proses ekonomi di serahkan kepada mekanisme pasar dengan pelakunyapelakunya terdiri dari para usahawan swasta. Dengan demikian tidak dikehendaki lagi bahwa pimpinan-pimpinan produksi berada di tangan para pemerintah, melainkan di tangan manager-manager swasta.

Penetrasi-penetrasi dari budaya barat atau western tersebut membuat masyarakat Indonesia hingga saat ini cenderung untuk bertingkah laku menurut suatu kerangka atau pola perilakuan yang sudah membudaya yaitu dari budaya hukum yang datang dari Barat . Pada dasarnya Kultur membentuk suatu struktur , pada gilirannya struktur mempengaruhi sikapsikap, karena struktur mendefinisikan apa yang mungkin berlangsung, menetapkan apa yang dipandang lazim ${ }^{10}$. Sehingga apabila kultur asli di Indonesia di dominasi dengan kultur barat yang dimaksud dalam uraian ini merupakan kultur yang mengarahkan ke arah yang negatif maka secara otomatis tingkah laku masyarakat Indonesia akan mengikuti apa yang sesuai dengan kultur yang berkuasa di dalamnya. Hal ini berdampak pada hukum yang diterapkan 
dalam era globalisasi saat ini, misalnya saja seperti jargon-jargon hukum yang biasa dipakai di negara-negara liberal yang diterapkan di Indonesia misalnya saja negara liberal selalu menjunjung tinggi yang dinamakan netralitas hukum, otonomi hukum dan objektifitas hukum.

Namun pada kenyataannya netralitas dalam hukum hanya omong kosong belaka terjadi suatu kepemihakan di dalamnya yang diperuntukkan bagi orang-orang yang memiliki kuasa di negaranya hal ini diadopsi pula dalam hukum di Indonesia, sama halnya dengan negara liberal netralitas hukum di Indonesia perlu dipertanyakan sebagai contohnya berapa banyak koruptor-koruptor di Indonesia yang di vonis bebas oleh pengadilan Tipikor di Indonesia hanya karena para koruptor tersebut dahulunya menjabat sebagai gubernur, bupati, walikota aataupun pemangku jabatan penting di lembaga-lembaga negara, secara tidak langsung Indonesia melupakan dasar dari negaranya sendiri yaitu demokrasi yang berubah menjadi liberal secara tidak langsung.

Untuk otonomi hukum pun di Indonesia tidak berjalan dengan baik dengan perkembangan-perkembangan hukum di era globalisasi sama halnya dengan mencontoh atau meniru gaya hukum negara liberal otonomi hukum yang berprinsip bahwa hukum itu otonom tidak ada campur tangan dari unsur-unsur yang lain namun dalam prakteknya hukum menjadi tidak otonom kembali karena produk hukum saat ini yang dibuat di Indonesia merupakan produk yang secara tidak langsung ditujukan bagi kepentingan politik bagi para pembuatnya, masyarakat Indonesia saja yang tidak peka hanya dengan gaya bahasa hukum disetiap perundang-undangannya yang dibuat susah untuk dimengerti dan dibuat dengan gaya bahasa setinggi mungkin kita dapat langsung saja percaya apa yang telah dikeluarkan oleh pembuat undang-undang itu sendiri. Pada kenyataannya produk hukum yang dikeluarkan lebih menguntungkan bagi golongan-golongan pembuat hukum itu sendiri kembali lagi pada kepentingan individu-individu, bukan bagi kepentingan masyarakat.

Yang ketiga yaitu mengenai objektifitas hukum dimana di negara liberal maksud dari objektifitas hukum yaitu kenyataan adalah tempat berpijaknya hukum itu pun sebagai pengecoh masyarakat agar percaya bahwa hukum di negara-negara liberal merupakan hukum yang objektif penerapannya sesuai dengan kenyataan namun dalam prakteknya bahwa hukum itu tidak lagi objektif namun berubah menjadi subjektif dengan melihat subjek-subjek di dalamnya. Apabila subjeknya merupakan penguasa ataupun orang yang penting di negaranya maka hukum itu menjadi subjektif tidak lagi melihat dari kesalahan yang telah dibuat oleh 
yang bersalah . Hal ini, pula yang ditiru oleh negara kita, dapat kita temukan dengan mudah di negara kita .

Sebagai contohnya besan dari presiden kita Susilo Bambang Yudhoyono yaitu Aulia Pohan ia telah mendapat grasi dan remisi tak tanggung-tanggung ia mendapat potongan hukuman selama 6 bulan dan ia langsung dibebaskan secara bersyarat padahal jika sesuai dngan aturan maksimal pemberian masa potongan hukuman adalah 2 bulan. Contoh dari kasus itu saja sudah membuktikan bahwa negara kita di era globalisasi bukannya memperbaiki hukumnya bagi kepentingan masyarakat akan tetapi memperbaiki hukumnya bagi kepentingan pejabat, penguasa di negeri ini, sekali lagi telah dilupakan apa yang namanya negara demokrasi itu sendiri.

Selain hukumnya yang telah banyak dipengaruhi oleh budaya barat, tingkah laku pembuatnya pun telah dipengaruhi oleh budaya barat yang secara mudah masuk di Indonesia misalnya saja individu-individu yang diutamakan, kepentingan golongan yang diutamakan mereka, mereka tidak pintar untuk menyaring mana yang baik dan patut dicontoh bagi perkembangan hukum di negaranya sendiri yaitu Indonesia dan mana yang tidak patut di contoh dan diterapkan di negaranya yaitu Indonesia.

Di era globalisasi ini hukum Indonesia sendiri yang menjadi penindas negara nya sendiri terutama masyarakatnya sendiri. Tidak ada lagi yang dinamakan keterikatan antar anggota masyarakatny, tidak ada lagi yang namanya menjaga dan melestarikan alam di negerinya sendiri kita dapat lihat di provinsi papua, dimana eksploitasi pertambangan secara besarbesaran terjadi disana masyarakat papua sendiri tidak dapat melakukan apa-apa kaarena pemerintah sendiri yang telah melakukan kontrak ke sejumlah pihak maka dengan didasarkan dengan perjanjian-perjanjian itu maka perusahaan-perusahaan besar milik asing ataupun perusahaan milik negara-negara liberal yang memiliki jiwa kapitalisme mencari keuntungan sebesar-besarnya di negeri orang guna mendapat keuntungan yang besar di tanah papua, dimana kekayaan alam yang besar masih banyak tersimpan di tanah papua. Hal ini merupakan bukti dari hukum kita yang bukannya berkembang ke arah yang lebih baik namun hukum kita yang telah di dominasi oleh budaya-budaya hukum barat. Di provinsi Papua saja yang memiliki kekayaan sumber daya alam yang besar namun berbalik $180^{\circ}$ apabila kita melihat kondisi-kondisi setiap penduduk aslinya, tetap saja sampai kapanpun seperti itu membeku, tidak bergerak maju, dan akan selalu tetap tertinggal dari yang lain. 


\section{Membangun Budaya Hukum Indonesia Berawal Dari Membangun Kesadaran}

\section{Masyarakat Dalam Wacana Demokrasi Yang Sesungguhnya}

Pemikiran diatas merupakan awal dari bagaimana suatu masyarakat dapat menyaring segala perkembangan di era globalisasi yaitu melalui kesadaran hukumnya. Memang hal ini tidak mudah untuk dianalisis, sebab masyarakat Indonesia sendiri terdiri dari berbagai lapisan dan atribut sosial yang heterogen. Membangun budaya hukum di Indonesia menurut saya sebaiknya dimulai dari membangun kesadaran masyarakat terlebih dahulu terhadap hukum yang ada di negaranya dan dilatar belakangi dengan wacana demokrasi yang sesungguhnya yang saat ini pada kenyataanya tlah luntur tergeser dengan budaya-budaya barat yang masuk dan mendominasi budaya hukum di negara kita sendiri.

Di lain pihak, kesadaran hukum tidak hanya ditujukan kepada masyarakat, melainkan juga suatu lembaga yang terlibat dalam pengaturan negara. Membangun kesadaran masyarakat dalam wacana demokrasi sulit dapat tercapai seandainya tidak memperhatikan peranan pemerintah dalam aspek-aspek yang terkait dalam kesadaran hukum di era globalisasi ini.

Dengan demikian, kesadaran hukum dalam wacana demokrasi ,diartikan sebagai suatu keadaan dimana suatu masyarakat mematuhi dan mentaati suatu peraturan hukum tidak semata-mata sebagai kewajiban belaka, melainkan juga merupakan suatu kebutuhan dimana ketertiban dan keadilan tidak akan tercapai, ketika hukum penegakannya tidak berfungsi efektif, maka kita tidak dapat dengan serta merta mengharapkan demokrasi tanpa memahami hak-hak dan kewajiban dalam merealisasikan peraturan hukum. Nilai-nilai budaya setempat, terutama bila terjadi kontradiksi antara kedua nilai yang saling berbeda. Dalam konteks masyarakat Indonesia, dua hal penting yang perlu diperhatikan, Pertama, Proses pembelajaran hukum sebagai pengetahuan; Kedua, proses pembelajaran kesadaran normatif hukum melalui fakta-fakta sebagaimana norma hukum dapat dikonfirmasikan melalui peranan efektif penegak hukum.

\section{Proses Pembelajaran Hukum Secara Normatif ${ }^{11}$}

Usaha untuk mendengar (listen) dalam menumbuhkan kesadaran hukum bisa berangkat secara individual maupun kolektif. Pendengaran begitu penting dalam menumbuhkan kesadaran hukum, oleh karena hukum mengandung ajaran-ajaran, kaidah-kaidah mengenai

Jawahir Thontowi , Budaya Hukum dan Kekerasan Dalam Dinamika Politik Indonesia, Jogjakarta: UII Press, 2001 , hlm. 5-6. 
perintah dean larangan yang harus segera dipatuhi dan dilaksanakan. Proses pembelajaran pengetahuan hukum melalui proses mendengar biasanya timbul di kalangan masyarakat tradisional dimana tradisi penyampaian dari mulut ke mulut begitu efektif. Sekalipun demikian, penyampaian dari mulut ke mulut tetap menjadi salah satu cara paling efektif dalam menyampaikan pesan-pesan pada masyarakat. Akan tetapi, tradisi dari mulut ke mulut ini semakin hari tidak dipergunakan sebagai satu-satunya alat komunikasi, karena cara ini bisa juga menimbulkan kesalahpahaman, biimana pesan itu tidak mampu didengar dan diterima secara tepat.

Suatu kesadaran hukum akan tumbuh apabila didasarkan kepada pemahaman dengan melihat dan membaca. Istilah see tidak sekedar mengandung arti melihat namun juga bisa memahami. Kata-kata You see or I see, tidak berarti apa yang kamu lihat atau saya lihat, melainkan anda paham atau yang saya mengerti. Sama halnya dengan bahasa Arab , kata basharan atau bashirun yang artinya melihat, secara fungsional penglihatan ini juga bisa berarti qoro'a ( membaca ). Dalam Islam kata iqro' berkonotasi aktif, sehingga dengan membaca, informasi salah yang diperoleh melalui tradisi mulut akan terkoreksi.

Peraturan hukum yang diperoleh dari sumber hukum, selain berguna sebagai dasar atau dalil bagi benar atau salahnya suatu perkara, juga kesalahan-kesalahan yang mungkin terjadi dapat dihindari. Itulah sebabnya penegak-penegak hukum dituntut untuk banyak membaca, sebab kegiatan membaca merupakan kunci awal kemampuan memformulasikan suatu norma ke dalam realitas. Spekulasi-spekulasi ilmiah dalam ilmu sosial bisa saja berangkat dari logika praktis, akan tetapi dalam analisa hukum membaca sumber-sumber hukum yang otentik mutlak diperlukan. Suatu bangunan argument yuridis akan menjadi lebih tangguh bilamana hasil bacaan itu juga dilengkapi dengan fakta-fakta hukum di lapangan. Apakah memang informasi yang diperoleh dari hasil bacaan itu memiliki kualitas fakta yang shahih atau tidak shahih, sehingga apa yang di dengarkan dan apa yang dibaca atau diteliti terdapat kesesuaian. Suatu kesadaran hukum tidak akan pernah tercipta bilamana pengetahuan normatif melalui tradisi lisan dan membaca tidak menemukan kesesuaian dalam kenyataan. 


\section{Praktek Pembelajaran Melalui Penegakan Hukum ${ }^{12}$}

Konfirmasi informasi sangat diperlukan dalam membangun kesadaran hukum tidak lain agar apa yang diyakininya sebagai benar, tidak diklaim sebagai kebenaran absolute. Efek dari klaim kebenaran absolute bisa menafikan kehadiran orang lain dan bahaya egoistik. Mental egoistik ini berubah pada sikap yang toleran, terutama ketika setiap individu pendukung nilainilai demokratis sadar bahwa selain ada tuntutan hak-hak asasi , juga ada tuntutan untuk pemenuhan kewajiban. Di satu pihak lain, baik negara maupun aparat penegak hukum berkewajiban memberikan hak-hak dan perlindungan hukum secara adil. Contoh yang erat kaitannya dengan kesederajatan hukum, dan mestinya masyarakat mengkonfirmasi dari contoh-contoh yang diberikan oleh figure hukum, bagaimana masyarakat akan sadar hukum bilamana penegak hukumnya menyimpang dari prinsip-prinsip hukum. Banyak sekali contoh kasus penegak hukum yang memang menyimpang dari prinsip-prinsip hukum misalnya saja di Indonesia banyak sekali kasus penyuapan hakim, jaksa , advokat bahkan polisi hal ini yang telah menjadi budaya hukum yang dilakukan penegak hukum sendiri di Indonesia misalnya saja kasus jaksa Urip, jaksa Cirus Sinaga dan masih banyak kasus lainnya, akhirnya yang terjadi adalah pelaksanaan hukum di Indonesia tidak lagi netral namun memihak dan kepemihakan itu digunakan sebesar-besarnya bagi yang memiliki kuasa di negara kita ini sungguh menyimpang jauh dari wacana demokrasi.

Oleh karena itu, tidak mungkin usaha sepihak untuk meningkatkan kesadaran hukum masyarakat dapat tercipta bilamana action yang terkoordinasi melalui law enforcement aparat negara, khususnya lembaga hukum yang memberikan langkah konkret dengan penuh kepastian. No action Talking only, ternyata masih berlaku di sebagian jajaran penegak hukum sehingga terlalu sukar untuk dapat mengidentifikasi tauladan-tauladan mana yang relevan dalam membangun kesadaran hukum sehingga dapat diwariskan kepada generasi berikutnya.

Apabila action konkret dari pihak penguasa sebagai pemegang kedaulatan negara atau rakyat tidak bisa lagi diandalkan sebagai arena pelembagaan kesadaran ( ketaatan dan kepatuhan secara hukum akan tegaknya ketertiban dan keadilan ), maka pada gilirannya masyarakat menggunakan suatu tekanan dan pemaksaan, sehingga pemerintah benar-benar dapat dijadikan tauladan. Dalam realitasnya, harapan ini tidak tercapai dan berakhir dengan

\footnotetext{
12 Jawahir Thontowi, Ibid, hlm. 7-8.
} 
kekecewaan mendalam pada masyarakat. Supremasi hukum yang menjadi kedaulatan negara , sebagian telah menjadi bagian dari wewenang rakyat.

\section{Membangun Budaya Hukum Di Indonesia}

Berbicara mengenai budaya hukum, bukan sekedar membhas hukum dalam konteks perubahan sosial semata, melainkan juga melihat bagaimana sistem hukum yang satu berinteraksi dengan nilai-nilai sosial budaya lainnya. Konsekuensinya , budaya hukum dalam suatu negara tidak saja mengakui adanya sistem hukum lain , baik sistem hukum yang datang dari kebiasaan masyarakat maupun yang timbul dari norma-norma hukum keagamaan .

Legal pluralism suatu negara selain mengenal hukum kolonial ( Eropa-Belanda ) untuk menciptakan ketertiban, juga tidak bisa menyampingkan kompleksitas sistem hukum sebelumnya. Terdapat tiga komponen penting yang perlu dikemukakan dalam hubungannya dengan membangun budaya hukum Indonesia.

Pertama, pembangunan budaya hukum yang berkaitan dengan reformasi peningkatan kualitas hukum substantif . Kedua, tegaknya budaya hukum berkaitan dengan peranan struktur atau lembaga-lembaga hukum dalam masyarakat. Ketiga adalah, faktor budaya yang berlaku pada masyarakat ${ }^{13}$.

Untuk membangun budaya hukum Indonesia, perlu proses pembuatan undang-undang yang memihak pada perlindungan hak-hak masyarakat, dan dibutuhkan peningkatan biaya bagi penegakan hukum serta pengawasan secara terpadu. Akan tetapi, proses pembangunan budaya hukum ini tergantung kepada usaha memulihkan kepercayaan masyarakat terhadap supremasi hukum . Bilamana masyarakat meragukan eksistensi pemerintah yang bersih pada saat ini, maka hasrat untuk mengubah sistem dan keyakinan masyarakat terhadap Pancasila dan Undang-undang Dasar Republik Indonesia Tahun 1945 menjadi langkah yang sangat strategis.

\section{Prinsip-prinsip negara hukum guna membangun budaya Hukum indonesia}

Berbicara mengenai usaha membangun budaya hukum Indonesia dari segi substantif (material), menjadi sangat penting untuk menyegarkan kembali berdirinya Republik Indonesia . Sebagaimana dalam pembukaaan UUD RI 1945 , Indonesia berdasarkan negara

Jawahir Thontowi, Budaya Hukum dan Kekerasan Dalam Dinamika Politik Indonesia, Jogjakarta: UII press, 2001 , hlm. 10. 
hukum (rechtstaat) dan bukan merupakan negara kekuasaan ( machtstaat) mengembalikan prinsip-prinsip dasar negara hukum dalam arti konseptual dan fungsional tidak dapat dihindari.

Perwujudan kembali Demokrasi yang sebenar-benarnya di negara kita pun tidak luput untuk ditegakkan guna membangun kembali budaya hukum di Indonesia apalagi di era globalisasi dimana budaya barat terus menerus dan mendominasi budaya hukum Indonesia . Pada dasarnya demokrasi hanya mungkin berjalan di negara kita dengan rule of law . Supremasi hukum dan rule of law baru bisa ditegakkan dan harus ditegakkan secara demokratis apabila peraturan perundang-undangan ditetapkan sendiri oleh rakyat melalui lembaga perwakilannya. Karena demokrasi adalah ialah kebebasan yang diselenggarakan dengan ketertiban dan ketertiban dengan kebebasan ${ }^{14}$.

A.V Dicey dalam bukunya Law and the Constitution menyebutkan, the rule of law atau rechtstaat menegaskan : pertama, the rule of law harus diselenggarakan dalam suatu pemerintahan yang mengutamakan supremasi hukum dan menghindarkan kekuasaan yang sewenang-wenang : kedua, the rule of law harus menempatkan kesederajatan untuk menaati peraturan hukum ( equality before the law ). Ajaran ini mengharuskan setiap permasalahan diselesaikan melalui peradilan dengan menolak adanya haka-hak istimewa ${ }^{15}$.

Namun pada kenyataannya di negara kita ini supremasi hukum, demokrasi tidak berjalan sesuai yang dikehendaki semua tergeser di era globvalisasi ini, banyak sekali penegak hukum maupun masyarakat sendiri tidak secara bijaksana menyaring berbagai kemajuan teknologi dan informasi sehingga bukan perbaikan budaya hukum Indonesia yang maju dan berkembang melainkan budaya hukum western yang telah mendominasi negara kita sendiri. Atas dasar berbagai kelemahan tersebut, perlu kiranya kemauan melakukan amandemen terhadap UUD RI 1945, diorientasikan kepada terciptanya UUD yang mampu merespon era Globalisasi. Robertson menyebutkan tiga aspek penting globalisasi yang seyogyanya oleh setiap negara perlu dipertimbangkan. Aspek pertama, masyarakat nasional cenderung semakin hari menempatkan heterogenitas, yang secara internal maupun eksternal dan pada waktu yang sama mereka mengalami suatu desakan untuk membangun kembali identitas masing - masing sepanjang garis kebinekaan. Aspek kedua, individu yang cenderung sebagai

\footnotetext{
$14 \quad$ Mukhtie Fadjar, Tipe Negara Hukum, Malang: Bayumedia, 2005, hlm. 77-78.

15 Jawahir Thontowi, Budaya Hukum dan Kekerasan Dalam Dinamika Politik Indonesia, Jogjakarta: UII press, 2001 , hlm. 11-12.
} 
subjek dari suatu persaingan suku, budaya dan segi-segi keagamaan. Aspek ketiga, yaitu sistem hubungan Internasional (the system of International relation) yang semakin menyebar luas. $^{16}$

\section{Amandemen Dan Aspirasi Nasional}

Rumusan normatif mengenai negara hukum yang berdasarkan kedaulatan rakyat seperti disebutkan oleh UUD RI 1945 , dalam pelaksanaannya dapat melakukan penyimpangan . Di pihak lain rakyat melalui wakilnya di DPR tidak memperoleh kemudahan dalam melakukan pengawasan. Secara konstitusional tidak ada alas an yang dapat dipertahankan untuk menjadikan UUD RI 1945 sebagai kitab suci . Seorang orator dari Yunani, Demothenes ( 384-322 BC ) mengajukan pandangannya mengenai fungsi hukum dihadapan para juri diantaranya sebagai berikut ${ }^{17}$ :

1. Tujuan tegaknya hukum adalah tercapainya keadilan, kehormatan, martabat serta kemanfaatan .

2. Dilihat dari sistem norma dan fungsinya, hukum itu sebagai temuan atau hadiah dari

Tuhan, suatu putusan dari orang-orang bijak, berfungsi sebagai suatu alat yang mengoreksi kesalahan-kesalahan seseorang secara sengaja atau tidak, yang berlaku pada suatu negara.

3. Dari segi penegakannya, hukum suatu pedoman dan perintah mewajibkan semua orang untuk mematuhinya dengan berbagai alasan, karena itu semua warga negara dan sesamanya adalah sederajat di depan hukum.

Di Indonesia sistem pemerintahan yang check and balance tidak akan tercipta. Salah satu akibat, berpusatnya kedudukan di tangan presiden telah terbukti prinsip kesederajatan hukum tidak bisa dilaksanakan. Contohnya saja di Indonesia presiden memilih menteri-menterinya yang sudah menjadi rahasia umum para perangkat-perangkat atau wakil-wakilnya adalah orang-orang dalam sendiri, yaitu memang orang-orang yang dekat dengan presiden seperti misalnya Kepala Staf Angkatan Darat ( KSAD ) adalah kakak ipar presiden sendiri , menbteri-menterinya salah satunya tim sukses presiden dahulu serta calon besan dari presiden kita, sehingga membuka peluang bagi pemimpin-pemimpin yang lain yang memang

\footnotetext{
${ }^{16}$ Ibid, hlm 15.

${ }^{17}$ Jawahir Thontowi , Budaya Hukum dan Kekerasan Dalam Dinamika Politik Indonesia, Jogjakarta: UII Press, 2001, hlm. 15.
} 
berkompeten dibidangnya agar penegakan hukum di Indonesia untuk masuk di dalam jajaran kabinetnya.

Selain masalah diatas masalah di dalam lembaga yudikatif pun menjadi permasalahan misalnya saja kepastian hukum bagi hakim relatif rentan . Pertama, Indonesia mengakui pluralisme hukum sehingga hakim mempunyai kebebasan untuk membuat pertimbangan dalam suatu putusan. Hanya saja hal itu akan tegak apabila hakim - hakim tersebut memiliki watak dan moral malaikat, yaitu amanah dan adil.

Kedua, yurisprudensi yang mengikat hakim-hakim terhadap putusan dapat dipergunakan atas kasus-kasus yang memiliki kesamaan. Hal ini penting untuk dijadikan prinsip dalam menegakkan kepastian hukum . Doktrin yurisprudensi berguna sebagai suatu parameter menegakkan kebenaran hukum bagi hakim-hakim tingkat Pengadilan Negeri ( PN ) dan Pengadilan Tinggi ( PT ). Lemahnya teori yurisprudensi tidak akan efektif bilamana hakimhakim Agung juga tidak menegakkan kebenaran dan keadilan hukum.

\section{Aspirasi Individu , Suku Dan Agama}

Kenyataan Indonesia sebagai negara kesatuan, terdiri dari berbagai suku, bangsa dan agma yang berbeda - beda telah melahirkan perubahan sikap yang mendasar terhadap rasa dan jiwa nasionalisme. Timbulnya isu disintegrasi telah mengancam eksistensi negara kesatuan Indonesia. Salah satunya disebabkan karena UUD RI 1945 tidak bisa dijadikan instrumen hukum efektif dalam menciptakan timbulnya proses interaksi sosial, dimana semua pihak terlayani secara seimbang, pantas dan adil. Keberadaan hukum substantif, baik yang berada dalam batang tubuh UUD RI 1945 , khususnya mengenai otonomi daerah dan juga UU mengenai pemilikan tanah dan perlindungan terhadap hak-hak masyarakat memang belum mengakomodasikan arus globalisasi, terutama yang berkaitan dengan fungsi peraturan hukum yang mampu menekan timbulnya konflik yang diakibatkan oleh motif-motif individu, suku dan agama.

Memudarnya semangat persatuan Indonesia dan meningkatnya tuntutan kelompokkelompok sosial, kesukuan, dan keagamaan juga disebabkan oleh terbentuknya pemusatan kekuasaan. Tuntutan Otonomi Daerah dalam pengaturan anggaran belanja tahunan semakin membuktikan adanya keinginan menetapkan federal sebagai bentuk yang ideal untuk daerahdaerah tertentu seperti Aceh dan Papua. 
Kebijakan pemerintah pusat yang terkadang menggusur pemilikan hak-hak atas tanah rakyat, dan lebih menyinggung bilamana tanah-tanah yang dijadikan sasaran pembangunan adalah dikuasai oleh kelompok masyarakat dari suatu agama tertentu . Tanah lot yang terdapat candi-candi ditetapkan menjadi tempat pariwisata . Tiadanya perlindungan kuat terhadap hak-hak pemilikan rakyat salah satunya disebabkan oleh UU nomor 5/1960 ( Undang-undang Pokok Agraria ) .

Dalam Pasal 3 disebutkan bahwa hak milik atas tanah memiliki fungsi sosial. Artinya, tanah dan bangunan di atasnya seperti candi - candi , masjid dapat dikuasai. Lebih parah lagi ketika masyarakat harus menyerahkan tanah-tanah milik mereka oleh karena adanya suatu proyek pembangunan. Banyak kasus seperti di Kedung Ombo di Jawa Tengah, kasus Nipa di Madura telah menyinggung martabat masyarakat local. Ketidakpuasan masyarakat, bukan sekedar disebabkan oleh tidak sepadanannya konpensasi ganti rugi melainkan cara pencabutan hak bukan oleh Undang-undang. Suatu proses penarikan hak-hak rakyat, yang dilakukan melalui surat Kepres, SK Gubernur atau Bupati / Walikota bernuansa penekanan ( repressive) .

Bilamana hak pemilikan itu dilindungi oleh undang-undang, maka pencabutan hakhaknya itu juga harus menggunakan kekuatan yang sejajar. Dengan demikian , bilamana caracara secara hukum ditepati maka aspirasi rakyat melalui lembaga legislatif dapat diakomodir . Hal ini juga berarti, akan menimbulkan tegaknya pemberdayaan peranan DPR Pusat dan Daerah dalam ketertiban yang ternyata dapat menyelesaikan suatu pertikaian.

\section{SIMPULAN DAN SARAN}

\subsection{Simpulan}

Budaya hukum di Indonesia sendiri telah tergeser dengan suatu budaya hukum yang baru yang disebabkan oleh berbagai hal misalnya saja semakin majunya teknologi seolaholah kita dapat melintasi tapal batas antar negara, semakin berkembangnya perdagangan bebas di Indonesia, informasi-informasi yang semakin ter update dan masih banyak penyebab yang lainnya. Selain dampak positif yang telah diberikan oleh berbagai kemajuan di era globalisasi ini dampak negatif pun turut serta mewarnai segala sesuatunya di negara kita. Contohnya saja dengan masuknya budaya western pemikiran kita pun menjadi western pula dapat kita lihat yang awalnya negara kita merupakan negara demokratis dari rakyat dan untuk rakyat semua serba sosial dan bagi kepentingan sosial pula maka saat ini secara tidak 
langsung negara kita bergeser menjadi negara liberal yaitu masyarakat yang kebanyakan memiliki jiwa individualisme, perekonomiannya pun bergeser yang awalnya di gembargemborkan suatu ekonomi kerakyatan di negara ini menjadi ekonomi kapitalisme sudah dibuktikan di negara kita yang berkuasa di setiap titik nadi perekonomian adalah yang bermodal tinggi dan yang tidak memiliki modal tetaplah menjadi kaum-kaum marginal di negeri sendiri tanpa adanya perubahan dari tahun ke tahun.

Untuk membangun budaya hukum Indonesia dan mengembalikannya, perlu proses pembuatan undang-undang yang memihak pada perlindungan hak-hak masyarakat, dan dibutuhkan peningkatan biaya bagi penegakan hukum serta pengawasan secara terpadu. Akan tetapi, proses pembangunan budaya hukum ini tergantung kepada usaha memulihkan kepercayaan masyarakat terhadap supremasi hukum . Bilamana masyarakat meragukan eksistensi pemerintah yang bersih pada saat ini , maka hasrat untuk mengubah sistem dan keyakinan masyarakat terhadap Pancasila dan Undang-undang Dasar Republik Indonesia Tahun 1945 menjadi langkah yang sangat strategis.

\subsection{Saran}

Di era globalisasi ini dimana budaya western sangat mudah masuk dan mendominasi budaya kita khususnya budaya hukum kita , kita sebagai bangsa Indonesia harus dengan cermat dan teliti untuk lebih bijaksana lagi dalam menyaring segala kemajuan teknologi informasi khususnya di bidang hukum. Karena pada dasarnya budaya hukum yang dipakai di negara kita harus tetap kita jaga karena merupakan identitas negara kita dan identitas diri semua bangsa Indonesia , jangan sampai hanya karena pesatnya budaya barat yang masuk kita melupakan ikatan-ikatan antar suku,agama,serta masyarakat sendiri, kita melupakan arti dari demokrasi dan berganti dengan arti liberal serta kapitalisme. Selain bangsa Indonesia seharusnyalah lebih teliti untuk menyaring budaya asing yang masuk dari dampak era globalisasi ini terlebih lagi penegak hukum nya pun seharusnya dapat memperbaiki mengatasi segala dominasi-dominasi budaya asing khusunya yang memberikan dampak negatif bagi kita, dan budaya yang menggeserkan budaya asli negara kita apalagi menghancurkan identitas dari negara kita ini.

Oleh karena itu meskipun budaya western atau barat masuk dan berkembang dengan pesat di Indonesia kita ambil segala contoh-contoh dan informasi yang baik dari budayabudaya hukum di negara lain guna memperbaiki sistem hukum yang ada di negara kita , 
bukan berarti mengaplikasikan semua budaya barat yang kita batasi pada budaya yang memang baik yang memberikan dampak positif pada hukum di Indonesia.

\section{DAFTAR PUSTAKA}

\section{Literatur}

Lili Rasjidi , Dasar-dasar Filsafat dan Teori Hukum, (Bandung: Alumni, 2007)

Satjipto Rahardjo , Hukum dan Perubahan Sosial, (Bandung : Alumni, 1983)

Lawrence M Friedman, Sistem Hukum Perspektif Ilmu Sosial, (Bandung: Nusa Media, 2009)

Jawahir Thontowi , Budaya Hukum dan Kekerasan Dalam Dinamika Politik Indonesia, (Jogjakarta: UII press, 2001)

Mukhtie Fadjar, Tipe Negara Hukum, (Malang: Bayumedia, 2005) 